Mr. Kennell A. Jackson, Jr. (Los Angeles, California): the oral traditions of the Kamba of Kenya.

Mr. Charles M. H. Keil (Chicago): Tiv creativity and semi-Bantu ethno-musicology.

Mr. William F. Lye (Los Angeles, California): the tribal history of the interior high veld of South Africa, $1822-37$.

Mr. Wyatt MacGaffey (Los Angeles, California): clanship, land tenure, and politics in the Lower Congo.

Mr. Robert C. Mitchell (Northwestern): the Aladuras and social change in Nigeria.

Mr. Philip A. Noss (Wisconsin): a linguistic description of the Yaiwe dialect of the Gbaya language.

Mr. Leo Spitzer (Wisconsin): Sierra Leone Creole intellectual history as reflected in writings and oral traditions.

Mr. Jack R. Stauder (Cambridge): ecology and social organization of the Majangir of south-west Ethiopia.

Mr. Richard E. Stryker (Los Angeles, California): community power and decision-making in Ivory Coast.

Grants for African Studies in the United States have been awarded to: Mr. Clement Cottingham (Berkeley, California); Mr. Bernth O. Lindfors (Los Angeles, California); Mr. Harold A. Olofson (Pittsburgh); Mr. Morris A. Simon III (Cornell).

\title{
The Society for African Church History
}

THE third Nigerian Sectional meeting of the Society for African Church History was held at the University of Nigeria, Nsukka, on 9 March $^{-} 966$, coinciding with the conclusion of the Consultation on Theological Education in Africa. Papers were presented by Dr. W. O. Ajayi (University of Ife) on Protestant missions in Northern Nigeria, Dr. J. T. BendorSamuel (Institute of Linguistics, Enugu) on missions and West African language study, Professor Paul Ellingworth (F. T. P. Yaoundé) on Dahomean Church history, Mr. E. M. T. Epelle and Mr. I. U. Nsasak on the methods and progress of the University of Nigeria scheme for the collection of church records, Professor N. Q. King (Makerere University College) on a projected history of Christianity in Africa, and Dr. H. W. Turner (University of Nigeria) on Independent churches.

The fourth London sectional meeting was held in the Africa Centre, King Street, W.C. I, on 3 I May. Professor A. D. Low of the University of Sussex was in the chair. The papers all related to Uganda. Mr. Trevor Williams presented a close examination of the beginnings of Christianity in Ankole; Miss Fay Carter examined Christian educational policy between the wars; and Miss M. Louise Pirouet outlined the aims and progress of the Makerere University College project for the collection of materials relating to Uganda religious history.

Dr. W. O. Ajayi has succeeded Mr. A. F. Walls as secretary of the Society. His address is Department of Comparative Religion, University of Ife, Ibadan, Nigeria. Mr. Walls will continue as the Society's editor, and the annual Bulletin, and the Bibliography of African Church History will henceforth appear from the Department of Church History, University of Aberdeen, Scotland.

\section{Deuxième Semaine d'Etudes Ethno-Pastorales à Bandundu}

Le Centre d'Études Ethnologique de Bandundu (relié à l'Institut Anthropos) a organisé au mois d'août I966 une deuxième semaine d'études ethno-pastorales sur le thème: ' La 
notion de Dieu et les croyances traditionnelles chez nos ethnies.' Cette réunion a été préparée par les participants - des Abbés, des Pères, des Sœurs (congolaises et européennes) et des moniteurs - durant dix mois de recherches personnelles sur place parmi les populations suku, yaka, mbala, yansi, boma et teke. A l'ouverture de la semaine d'études, l'organisateur, le Père Hermann Hochegger, S.V.D., donna un aperçu sur l'état actuel de nos connaissances et montra l'insuffisance de la terminologie conventionnelle. Les deux premières journées furent consacrés à l'étude de la notion de Dieu, et les participants exposèrent par la suite leurs recherches concernant le culte des idoles (biteke, bankisi). La dernière journée fut consacré à l'étude des idées maîtresses de la sorcellerie. A la fin des travaux, Monseigneur François Hoenen, Évêque de Kenge, qui avait suivi personnellement toutes les réunions, remercia les participants du bon travail accompli et insista auprès d'eux que les connaissances acquises soient mises en application dans l'apostolat. Les rapports et le compte rendu de la deuxième Semaine d'Études seront publiés par le Centre d'Études Ethnologique de Bandundu.

\section{Université Officielle du Congo, Lubumbashi: Colloque sur la Dot}

Sous le haut patronage de Son Excellence Monsieur le Gouverneur et de Monsieur le Ministre de la Justice du Sud-Katanga, de Monsieur le premier président de la cour d'appel de Lubumbashi, de Messieurs le Recteur et les Vice-Recteurs de l'Université Officielle du Congo, de Monsieur le Directeur du CEPSI (Centre d'Études des Problèmes Sociaux) à Lubumbashi, le Centre de Recherches de Droit Coutumier a organisé du I 4 au 17 novembre I 966 un colloque sur la dot. Il avait pour but d'étudier la dot dans sa situation actuelle et de dégager des propositions pour l'avenir. Le colloque était sous la direction du Professeur E. Lamy.

\section{International Institute for Labour Studies: Fast African Seminar}

THE Swedish International Development Authority has agreed to finance the East African Seminar on Labour Problems in Economic Development, organized by the International Institute for Labour Studies. The Seminar will be held in Nairobi, Kenya, from i April to I May 1967, and will be attended by thirty participants, who are being chosen by an Institute selection mission headed by Professor Kenneth Walker.

\section{University of Cambridge: Centre of African Studies ${ }^{\mathrm{I}}$}

DR. JACK Goody has been appointed as Director of the Centre in succession to Dr. Audrey Richards, who retired in October 1966. Mrs. Jane Whiter has become Secretary-Librarian on the resignation of Miss Julia Allen. The Committee of Management of the Centre is composed of representatives from the faculties of Agriculture, Archaeology and Anthropology, Economics and Politics, Geography, History, and Law.

The Centre is currently engaged on two research projects: (I) The Big Farmer Project, under the joint direction of the Centre and the Cambridge School of Agriculture, is a study of the conditions in which African peasants have successfully taken the step from the traditional subsistence cultivation to commercial farming. The first area selected for study is south Uganda and it is hoped to choose a second area for comparative study later. T'wo research fellows are engaged on the scheme, a social anthropologist, Mr. Archie Mafeje, and an economic geographer, Mr. David Hougham. (2) The history and organization of

I See also Africa, xxxvi, Aptil 1966, p. 199; Africa, xxxvi, July 1966, pp. 324-5, for accounts of the Centre's library and bibliographical work. 